\title{
BETWEEN PATH DEPENDENCY AND CONTINGENCY: NEW CHALLENGES FOR THE GEOGRAPHY OF PORT SYSTEM EVOLUTION
}

This is the pre-published version of the text. The final published paper can be found at: Monios, J., Wilmsmeier, G. (2016). Between path dependency and contingency: new challenges for the geography of port system evolution. Journal of Transport Geography. 51: 247-251.

DOI: doi:10.1016/j.jtrangeo.2016.01.008

\section{Introduction}

Seaports play a critical role as gateways and facilitators of economic interchange and logistics processes and thus have become crucial nodes in globalised production networks and mobility systems. Both the physical port infrastructure and its operational superstructure have undergone intensive evolution processes in an effort to adapt to changing economic environments, technological advances, maritime industry expectations and institutional reforms. The results, in terms of infrastructure, operator models and the role of an individual port within the port system, vary by region, institutional and economic context. While ports have undoubtedly developed in scale to respond to the changing volumes and structures in geographies of trade (Wilmsmeier, 2015), the development of hinterland access infrastructure, regulatory systems and institutional structures have in many instances lagged behind. The resulting bottlenecks reflect deficits in the interplay between the economic system and the factors defining port development (e.g. transport demand, the structure of trade, transport services, institutional capacities, etc. cf. Cullinane and Wilmsmeier, 2011). There is a wide range of case study approaches and analyses of individual ports, but analyses from a port system perspective are less common, and those that exist are seldom critical of the dominant discourse assuming the efficiency of market competition (cf. Debrie et al., 2013).

This special section aims to capture the spectrum of approaches in current geography research on port system evolution. Thus the papers reach from the traditional spatial approach (Rodrigue and Ashar, 2016) to network analysis (Mohamed-Chérif and Ducruet, 2016) to institutional discussions (Vonck and Notteboom, 2016; Wilmsmeier and Monios, 2016). The selection of papers allows an opening of discussion and reflection on current research, necessary critical analysis of the influences on port system evolution and, most importantly, 
future directions. The remainder of this editorial aims to reflect on these challenges and identify the potential for future research.

\section{Approaches to port geography - past and present}

In the search for future directions in port geography research, it can be helpful to consider whether previous concerns have been sufficiently resolved. From this perspective, Hartshorne's (1939; p. 203) apprehension that "Even if we knew the theoretical principles governing the relation of each individual factor to the total result . . . the sum total of all relationships ... would be far too complicated for us to be able to use" reads like a wake-up call for both current and future research. Has recent research delivered an understanding of the complex relationships and their governing principles? Has research describing existing phenomena sufficiently contextualized observations beyond the descriptive and questioned the emerging effects and alterations within the system of maritime transport and the wider system of cargo mobilities? Has port geography sufficiently theorized recent developments, influencing research and discussion beyond its own niche within geography as well as other disciplines?

Port development is path dependent to the extent that future action is reliant on past decisions, structures, processes and institutional contexts, but it is also contingent and openended as decisions may deviate from an existing development path. Numerous factors influence which path a port follows, but isolating the effects of individual influences is difficult in such a multifaceted and interdependent system. According to Debrie et al. (2013; p. 58) port governance studies generally "neglect to recognize a conceptual relation between time and space or between different spatial scales." Spatial studies of the geography of port system evolution have revealed trends of concentration and deconcentration as well as centralisation and decentralisation, each influenced by factors such as technological change in the maritime and port industry and port devolution processes in addition to vertical integration and competition strategies in the maritime industry (see section 3). Moreover, a port system might evolve in a reactive manner to such forces but can equally change as a result of proactive strategies of various stakeholders. Arguably the most difficult aspect of port planning, however, is recognising and dimensioning (spatial and temporal) new challenges yet to be faced.

The maritime and port systems provide a mirror to the current era of intensified and standardised global processes and production chains, where actors aspire to eliminate chokepoints between transport systems through standardisation and integration - to produce a 
"global surface of logistical integration" (Martin, 2013; p. 1023). Containerisation has been a key driver in this process and resulted in new demands for infrastructure development. While the shipping market remains very much a scale-driven industry, emerging developments are changing the source of port competitiveness from economies of scale based on basic production factors (capital, land, labour), to economies of scope based on advanced production (service) factors (Sánchez and Wilmsmeier, 2011). The nature of the required services is changing from standard services with long life cycles to differentiated service requirements which tend to have short life cycles.

The general trend of port geography research in recent decades has been away from traditional geographical approaches and towards more applied and operational perspectives ( $\mathrm{Ng}$ et al., 2014). Perhaps as a consequence of this trend, analysis of the significant concentration of ownership and operations of ports and shipping lines has, besides a few exceptions (e.g. Olivier and Slack, 2006; Wilmsmeier and Sánchez, 2011; Debrie et al., 2013), tended to accept this concentration as a fait accompli and address only the operational impacts. Thus, questions relating to the new conceptions and configurations of space, networks and power created through geo-economic and political imperatives as well as the corporatisation of the sector remain unanswered (Wilmsmeier and Monios, 2015).

\section{Conceptions of space in port geography}

Some of the early works of transport geography were contributed by geographers working in the port sector. Such early approaches to the geography of port system evolution were predominately taken from a spatial perspective (Bird, 1963; Taaffe et al., 1963; Rimmer, 1967; Hoyle, 1968; Hayuth, 1981; Barke, 1986; Van Klink, 1998). As the industry developed, analysis has turned to address port competition through hinterland accessibility (Notteboom and Rodrigue, 2005; Monios and Wilmsmeier, 2013), the structure of maritime services (Sánchez and Wilmsmeier, 2006; Rodrigue and Notteboom, 2010) and the influence of liner service concentration (e.g. Frémont and Soppé, 2007; Lee et al., 2008; Wilmsmeier and Sánchez, 2011, Wang and Ducruet, 2012).

A key spatial principle established by port geographers is that port system concentration eventually reaches its limits (Barke, 1986; Hayuth, 1981), leading to a process of deconcentration (Slack and Wang, 2002; Notteboom, 2005; Frémont and Soppé, 2007; Ducruet et al., 2009; Wilmsmeier and Monios, 2013). Spatial approaches tend not to differentiate between spatial deconcentration that emerges upon failure of a system in a 
reactive manner, deconcentration that materializes from proactive port development strategies, and deconcentration that emerges from new economic and industrial development. Thus there tends to be an implicit assumption that port systems will follow a dependent path, with the result that potentially contingent elements are less visible.

The emergence and location of secondary ports (e.g. Slack and Wang, 2002; Wang and Ng, 2011, in China; Wilmsmeier and Monios, 2013, in the UK; Wilmsmeier et al., 2014, in Latin America) has not been explained satisfactorily by the natural location advantages that have in most cases driven the location of dominant ports. If such developments are instead driven by other factors, such as the planning and regulatory regimes in each country, then research is needed to uncover and classify them, particularly if they differ between regions rather than following a generic path. In order to address these issues, geographers should seek interdisciplinary methodologies incorporating institutional and economic approaches (Hall et al., 2006). More recognition is needed of the port's place in the market, meaning that transport geography must learn more from economic and political geographies, subdisciplines that perhaps devote more attention to contingent processes.

The intrinsic instability of capitalism as a mode of production (cf. the analysis of Harvey and Marx in Wilmsmeier and Monios, 2015) has far-reaching effects for our understanding of the port sector, because in order to avoid the inevitable devaluation as a result of overaccumulation, capital will shift geographically or be deferred, meaning that it is only ever fixed in space for a temporary period. According to Harvey (1985; p. 150): "Capitalism perpetually strives ... to create a social and physical landscape in its own image and requisite to its own needs at a particular point in time, only just as certainly to undermine, disrupt or even destroy that landscape at a later point in time. The inner contradictions of capitalism are expressed through the restless formation and reformation of geographical landscapes." This is particularly relevant for the port sector, because "the fixed capital required in the transport industry is extensive and a lot of it is embedded in the built environment as roads, rails, terminals, etc." (Harvey, 2006 [1982]; p. 378). Thus the "restless formation and reformation" of the port industry should be read critically by port scholars, alert to what it reveals about underlying processes of power and control.

\section{New challenges for port geography}

Since the 1980s significant changes have occurred in the way ports are owned and operated. Corporatization, commercialization, internationalization, devolution and 
privatisation of port operations are now global phenomena and have developed in step with the global dispersal of production (Notteboom and Rodrigue, 2005; Brooks and Cullinane, 2007; Ng and Pallis, 2010; Sanchez and Wilmsmeier, 2010; Jacobs and Notteboom, 2011; Notteboom et al., 2013). Yet Debrie et al. (2013; p. 58) caution that these reforms "cannot be understood without considering the ideological dimension of social and economic change in the 1980s." In this context Niekerk (2005) addresses the role of government regulation as a necessary means to derive the benefits of competition, to regulate the supply in order to avoid monopolistic exploitation and, in effect, to plan resource utilisation.

Despite a recent growth in the institutional analysis of port development $(\mathrm{Ng}$ and Pallis, 2010; Jacobs and Notteboom, 2011; Notteboom et al., 2013; Wilmsmeier and Monios, 2016), missing from previous analyses has been a critique of the role of the dominant neo-liberal narrative (Wilmsmeier and Monios, 2015). This criticism has been directed at geography more widely: Smith (2005; p. 894) writes that geographers should identify the "location of power that needs to be talked back to, challenged, or transformed." A lack of answers to such a challenge can be seen in transport geography and even more so in port geography, partly a result of the fact that earlier spatial models that still influence port geography today did not capture the inherent instability and the mismatch between state forms, material mobility and capital flows, a mismatch leading to contingent outcomes that need to be carefully traced and studied. Doel's “pointillist" $(1999,2000)$ critique suggests that geography as a discipline is overly focused on cartographic representations, leading to a superficial account that tends to the descriptive and misses key underlying processes that constitute space.

The maritime sector is inherently cyclical, with large investments often taking place at the peak of a cycle and resulting in over-capacity as the cycle dips towards the next trough. As container vessels become ever larger and the investments required by ports to accommodate them increase, the risk of losing services to another port and the penalty all grow greater. The industry's attempts to mitigate this uncertainty are based on replication of strategy and diversification of holdings, both standard approaches of today's global corporations.

Current events in port operation thus underscore capitalist tendencies of uneven development, a fundamental outcome of capitalism as a mode of production (cf. Wilmsmeier and Monios, 2015). Thus the expansion and geographical spread of global port operators might be argued to be symptoms of the efforts to stabilise the contradiction of territory fundamental to the deployment of capital. Ports, like oceans, have converted into "post political" spaces (Zizek, 1999) where global management strategies and often local and national technocratic administration have been converging and where a new imbalance 
between private and public as well as the local and global has emerged, at the expense of proactive and visionary governance and policies.

In this context, the work of Deleuze and Guattari $(1983,1987)$ applied to the port sector by Wilmsmeier and Monios (2015) shows the importance of relationality over territoriality, whereby the primacy of flows, whether material or financial, over space becomes obvious. Capitalism invoked by its agents is constantly trying to control and capture flows of money, desire, raw materials, and so on (Holland, 2013). The extent to which these flows follow well-worn path dependent channels or are disrupted by more contingent elements has yet to be adequately identified, partly due to methodological challenges but also perhaps due to an underappreciation of their significance to the wider study of port geography. The physical immobility of transfer points in which global mobility is embedded masks an institutional mobility, as ports are not simply physical spaces but complex organisations with varying levels of public and private ownership, goals and responsibilities (Monios and Wilmsmeier, 2015). Understanding the interplay between immobile infrastructure and institutions (e.g. transport infrastructure, in this case ports) and the mobility of goods, finance and people represented as flows is still developing and the extension of this interplay and rules of power are not yet fully understood or theorised.

According to Deleuze and Guattari (1983; p. 223), "Capitalism does not lead to the dissolution of feudalism, but rather the contrary," as it reinforces rather than overturns existing dominant economic relations. Thus the question becomes if the current economic system is utilising rent extraction from infrastructure (in this case ports) as a new geoeconomic form of feudalism? An indicator of this process might be the decoupling of growth in the financial sector from the "real" economy characterised by infrastructure and productive investment growth (ECLAC, 2015). What happens to a system in which ports, as nodes of material interchange, convert into elements of global investment strategies and thus become nodes of financial and virtual transactions (cf. Baird, 2013 on the role of private equity funds in port ownership)?

The importance of the temporal dimension and the deferment of crisis is particularly relevant when considering the long-term view of port system evolution and the port system as an autopoietic system, i.e. one that changes its state with each new input, meaning that when a time-lagged investment comes on stream, for example a terminal capacity expansion plan begun during a market peak, the market may then be in a trough meaning that the investment merely adds to the overcapacity crisis and makes the devaluation of the physical more extreme, in addition to increasing the exposure to financial markets and external decision 
makers. Can a port fulfil its role in a local setting when its performance might be judged by the contribution it is going to provide for a teacher's pension in a foreign country?

\section{The special section}

The editors of this special section invited papers that identify and examine new influences on port geography. The goal was to highlight new challenges that will determine the next two decades of port system evolution, particularly those trends that influence the balance of port systems between path dependency and contingency. The geographical areas covered extend beyond the more frequently covered regions of Europe and the US to Latin America and Africa, providing a wide coverage not only of physical spaces but also of different economic, institutional and cultural influences. From a spatial perspective, the papers address challenges in individual ports, port ranges and port regions. All of these perspectives provide valuable insight into the inter-related spatial scales in which ports are embedded.

Mohamed-Chérif and Ducruet (2016) explore the relationship between maritime network design and regional integration by examining the Maghreb region in North Africa, which remains poorly integrated commercially and logistically. Maghreb ports in general have long suffered from a lack of investment in modern infrastructure, land-use problems within large cities, limited hinterland accessibility, poor technical efficiency and burdensome customs regulations. This situation underscores the contradiction between a strong reliance of Maghreb's international trade upon sea transport and the poor conditions of its port infrastructure, suggesting a mismatch between the port, maritime and economic systems.

Although numerous port projects and investments have taken place in recent years, the authors show how gateway ports have tended to lose out to the concentration of traffic at a handful of major transhipment hubs in the Mediterranean. The authors identify an increase in trans-Maghreb maritime connectivity but this occurs mostly at the periphery of the system based on transit flows. Gateway ports attempt to overcome their position by a focus on hinterland accessibility, which is one of the key reasons behind the success of the TangierMed port development. The authors conclude that, without further regional integration in the transport and port sector, and sustained weaknesses in the industrial sector, results suggest the likely growing polarization of Maghreb traffic upon Tangier, whereby a majority of Maghreb ports remain secondary ports served by feeder vessels. This analysis reveals the difficulties of overcoming an embedded path dependency on major ports and the importance of regional cooperation that faces increased challenges in unique geographical contexts. 
Rodrigue and Ashar (2016) provide an overview of different spatial typologies for conceptualising transhipment patterns at ports across the globe. While transhipment today is a standard activity to connect different models of liner services across the globe in hub-andspoke and hierarchical networks, this activity has become more specialised, and a handful of hub ports have been chosen by global terminal operators. Other hybrid ports still retain a share of these flows, while other ports focus on their gateway role, handling a mix of direct calls and transhipped cargo. The question raised from this work is how will further vertical integration in the market affect these hub-and-spoke structures, whereby the search of global players for network efficiencies might affect port infrastructure development in particular regions?

The authors first use this typology to conduct a spatial analysis of the current state of global container transhipment before focusing on the Caribbean market. They also discuss the potential impacts of the expansion of the Panama Canal for US cargo, deriving the role of Caribbean transhipment ports in a variety of potential liner shipping configurations servicing the US East Coast via the Panama Canal. The authors conclude that in the short term current direct services will remain, but greater use of New Panamax vessels will incentivise increased use of Caribbean transhipment ports. They further speculate that factors such as frequency and reliability may play a greater role than economies of scale, underlining the potential of transhipment to accommodate and mitigate all these requirements. An emerging topic from this work is the effect of hub and spoke network evolution on competition in the liner market, following the questions raised by Sánchez and Wilmsmeier (2011) on the effect of quasimonopolistic market structures in liner services on a country's competitiveness. Potential market effects and risks are likely to increase with vertical integration and a replication of concentration at port level. These processes further augment the contrast between the local and global and raise questions for further research regarding the ability of local and regional institutional structures to harness global flows.

The spatial principles of concentration and deconcentration identified by earlier port geographers (discussed in section 3) are thus drawn out by these two papers, particularly their interaction with the wider logistics system that is one of the main drivers of such processes. These findings concur with influences on these trends identified in previous research (e.g. Wilmsmeier et al., 2014), such as economic development in a port's hinterland, port devolution strategies, the introduction of the private sector to port operations, the competitive relation between private operators, the interrelationship between private and public actors and a changing regulatory environment. Linking these first two papers of the special section with 
the next two papers reveals how spatial processes, while conforming to some degree to previous theoretical predictions, are nonetheless shaped by wider economic processes, institutional mediation and the exercise of power.

Wilmsmeier and Monios (2016) argue that port development is challenged not only by the generic influence of growing trade flows but by institutional conditions that tend to be regionally specific and contingent. The paper analyses the intersection of two clear trends in the evolution of port systems, decentralisation of port governance and deconcentration of port traffic. The goal is to identify how the institutional setting governing the spatial diversification of container port activity has changed as a result of this intersection and whether it is suitable to deal with new challenges as they arise. An additional question is whether the new institutional settings created by port reform in developing countries are suitable to support the successful application of port devolution policies imported from developed countries with different political and institutional histories.

Based on four national case studies of port reform in Latin America, the paper discusses how the interplay between structure and agency in the reform of port governance has in some cases created merely a new path dependency. Findings show that short-term gains in technical efficiency in individual ports contrast with a long-term loss of power from the public to the private sector and the lack of integrated transport and logistics policies necessary to support ongoing port development. The authors demonstrate that it is quite possible to move from an unresponsive and inflexible public path dependency to a similarly inflexible private path dependency.

Vonck and Notteboom (2016) critique the limitations of existing life cycle models of port development and seek to apply the panarchy theorem of Holling to the port setting. They argue that, as ports are complex adaptive systems, port dynamics can therefore be assessed using the three dimensions (connectedness, resilience and potential) and four phases of panarchy. The authors match panarchy properties (poverty trap, rigidity trap, regime shifts, etc.) to examples occurring in ports.

What the authors show is that panarchy can be used to explain early paradigm shifts in port geography, although the model needs additional application in future work to fully realise the match between previous life cycle models, other port development models (e.g. UNCTAD generations) and more recent sustainable development paradigms. The multiple distinctive scales with cross-scale interactions identified in this work raise interesting questions on how to create a fit between these scales, suggesting dynamic links with the matching framework approach (Baltazar and Brooks, 2007). A further question that emerges 
is if the panarchy model can be used to provide further insight into the interaction between the port, maritime and economic systems, particularly the extent to which future processes are truly path dependent on current structures or whether treating ports as complex adaptive systems allows an identification and even exploitation of more contingent elements. Resilience and adaptation are currently key aspects of port management, and while the empirical application in this paper is based on waterfront redevelopment and port sustainability challenges, additional examples can be explored in future work, thus developing an exciting and challenging research agenda.

These latter two papers of the special section, therefore, address the new challenges facing port geography from trends of commercialisation and devolution. These are not simple processes of privatisation but represent a complex interplay of regulation and institutional change, resulting in new dimensions of power. Such changes possess a strong economic component that was not addressed explicitly in the special section papers; this thread remains to be picked up by future authors.

The special section papers did not identify significant drivers for disruption of path dependent processes, suggesting the need for further research on the dynamics that could potentially underpin such institutional and regulatory change in response to governance deficits. This suggests that the issue of power remains under-explored in port geography in recent times. Challenges raised over two decades ago (e.g. Slack, 1993) must be refreshed and reimagined.

While the spatial and institutional concerns raised in section 3 were addressed by the papers in the special section, the geo-economic context highlighted in section 4 was not explored significantly, and represents a future challenge for geographers. The globalised structure of the port operations industry exemplifies what Harvey (1989) referred to as spacetime compression, which is the overcoming of spatial boundaries or distance by economies of scope, thus facilitating the increased mobility of capital (cf. organisational proximity vs spatial proximity - Hall and Jacobs, 2010). The fact that this space-time compression is a selective process that benefits some at the expense of others (Thrift, 1996; Knowles, 2006; Schwanen and Kwan, 2012) has been insufficiently addressed by port scholars, perhaps indicating a reluctance to treat ports within their geo-economic and political contexts.

The economic and institutional settings in which ports are now embedded require methods of analysis that go beyond those traditionally applied in transport geography, but port geography has not embraced critical, radical or relational geographies. Transport geography has traditionally had less engagement with the social production of space (Hanson, 
2000; Keeling, 2007; Shaw and Sidaway, 2010), nowhere more evident than in port geography, which may be characterised as suffering from what Smith (2005) sees as the coopting of geographers by the dominant neoliberal narrative. In the absence of a theoretical underpinning, purely descriptive approaches ignore the evidence of a capitalist trend towards oligopoly and the inevitable accumulation crisis to follow that leads to value destruction in one place and recreation in another. The role of geographers, then, should be to provide such a foundation, based on analysis of the influence of capital on the production of space.

\section{Conclusion}

“With standardized products, a chaotic market tends towards ruinous competition." (Clark, 1940)

Transferring the citation from Clark to the context of port development, it might be argued that with standard national institutional approaches and frameworks a chaotic and global market will tend towards ruinous competition. Evidence of this might be found by glancing at headlines in the shipping press over the last few years, painting a picture of huge overcapacity and rock bottom freight rates. Greater attention to the institutional, regulatory and economic influences on strategic decision making in the industry may help to deepen our understanding of the spatial outcomes of port system evolution. It is in this sense that the port sector balances somewhere between path dependency and contingency, with various factors influencing both ends of the spectrum.

Recent studies observe competitive convergence of global operators horizontally and vertically, redefining competition space (Notteboom and Rodrigue, 2012). Despite such descriptive approaches charting the pattern of global terminal operator activities, the cultural and social geography of port reform has been insufficiently addressed, suggesting a failure on the part of geographers to engage in deeper analysis of the geographical, economic, institutional and social implications of such changes. While a broad recognition exists of power shifts resulting from the globalization of industrial relations, analysis of the spatiotemporal development of power in the port industry has been lacking and existing works remain descriptive.

Some papers in the special section focused less on the spatial perspective than the institutional, recognising how the institutional setting in which ports are embedded plays an influential role in their development arc. Successful attempts to break path dependency 
depend to a large extent on whether processes of port reform actually addressed the previous institutional setting or merely took place within the existing dependent path. Accordingly, there is some evidence that port reform may simply shift from one path dependency (generally an inflexible and inefficient public sector model) to another (a global port terminal operator with its own development agenda unrelated to the local and regional economies in which the port is embedded). The economic dimension discussed in section 4 needs further work to bring out its role in such processes.

While the special section papers confirmed to some extent the often reactive nature of the governance of port system development, such processes need to be addressed not just descriptively but through critical analyses taking account of the crisis tendency in the capitalist environment (as discussed in section 3 and 4 of this editorial), requiring more engagement between geography and economics. When analysing port development, the papers did confirm the importance of regional context in understanding the balance between path dependence and contingency, signalling the requirement to engage with other areas of geography in order to explore these issues in more depth. This special section has addressed research questions relating to the impact of global changes in demand, competition and technology on port development and how these effects vary in different regions or countries. In order to develop these ideas further, we would very much like to see port geography take a more critical and reflective direction and integrate theory from economic and political geography. Our goal is to bring port studies out of its comfort zone in the maritime transport world. We want to encourage economic geographers to use the canvas of port development to explore larger theories and processes (as also recommended by Hall et al., 2006; Shaw and Sidaway, 2010). In short, we want to apply the following quotation of Harvey (2001) to the study of ports: "The question is not, therefore, what can an understanding of globalization tell us about geography but what can an understanding of geographical principles tell us about globalization, its successes and its failures, its specific forms of creative destruction, and the political discontents and resistances to which it gives rise." There is still much work to be done.

\section{References}

Baird, A.J. 2013. Acquisition of UK ports by private equity funds, Research in Transportation Business and Management, Volume 8, 158-165

Baltazar, R., Brooks, M. 2007. Port Governance, Devolution and the Matching Framework: A Configuration Theory Approach. In: Brooks, M. R., Cullinane, K. (Eds). Devolution, 
Port Governance and Port Performance. Research in Transport Economics. Elsevier, London.

Barke, M., 1986.Transport and Trade; conceptual frameworks in geography. Edinburgh: Oliver and Boyd.

Bird, J., 1963.The Major Seaports of the United Kingdom,London: Hutchinson and Co.

Brooks, M. R., Cullinane, K. (Eds.), 2007. Devolution, Port Governance and Port Performance. Research in Transport Economics. 17. Elsevier, London.

Clark, J. M. 1940. Toward a concept of workable competition. The American Economic Review. 30 (2): 241-256.

Cullinane, K.P.B. and Wilmsmeier, G., 2011. The contribution of the dry port concept to the extension of port life cycles. In: J.W. Böse (ed.) Handbook of Terminal Planning, Operations Research Computer Science Interfaces Series, Vol. 49. Heidelberg, Germany: Springer: $359-380$.

Debrie, J., Lavaud-Letilleul, V., Parola, F., 2013. Shaping port governance: the territorial trajectories of reform. Journal of Transport Geography. 27, 56-65.

Deleuze G., Guattari, F., 1983. Anti-Oedipus. Minneapolis: University of Minnesota Press.

Deleuze G., Guattari, F., 1987. A Thousand Plateaus. Minneapolis: University of Minnesota Press.

Doel, M., 1999. Poststructuralist Geographies: The Diabolical Art of Spatial Science. Edinburgh: Edinburgh University Press.

Doel, M., 2000. Un-glunking geography: spatial science after Dr Seuss and Gilles Deleuze. In: M. Crang and N. Thrift (Eds). Thinking Space. London: Routledge: 117-35.

Ducruet, C., Roussin, S., Jo, J-C., 2009. Going west? Spatial polarization of the North Korean port system. Journal of Transport Geography. 17 (5): 357-368.

ECLAC, 2015. Panorama de la Inserción Internacional de América Latina y el Caribe 2015. La crisis del comercio regional: diagnóstico y perspectivas, ECLAC, Santiago. Chile

Frémont, A., Soppé, M., 2007. Northern European range: Shipping line concentration and port hierarchy. In Ports, Cities and Global Supply Chains, Edited by: Wang, J, Olivier, D, Notteboom, T and Slack, B. 105-120. Aldershot: Ashgate.

Hall, P., Hesse, M., Rodrigue, J-P. (2006). Reexploring the interface between economic and transport geography. Environment \& Planning A. 38 (7): 1401-1408.

Hall, P. V., Jacobs, W., 2010. Shifting proximities: the maritime ports sector in an era of global supply chains. Regional Studies. 44 (9): 1103-1115. 
Hanson, S., 2000. Transportation: Hooked on speed, eyeing sustainability. In: Sheppard, E. and Barnes, T. J. (Eds.). A Companion to Economic Geography. Oxford: Blackwell: 468483.

Hartshorne, R., 1939. The nature of geography. A critical survey on current thoughts in the light of the past. Annals of the AAG, 29.

Harvey, D., 1985. The Geopolitics of Capitalism. in Gregory, D. and Urry, J. (eds.): Social Relations and Spatial Structures. London: 128-163.

Harvey, D., 1989. The condition of postmodernity: an enquiry into the origins of cultural change. Blackwell, Oxford England; Cambridge, Mass., USA.

Harvey, D., 2001. Globalization and the "Spatial Fix". geographische revue 2: 23-30.

Harvey, D., 2006. The Limits to Capital. New and fully updated edition. London: Verso.

Hayuth, Y., 1981. Containerization and the load center concept. Economic Geography, 57, $160-176$.

Holland, E. W. (2013). Deleuze and Guattari's A Thousand Plateaus. London: Bloomsbury.

Hoyle, B. S., 1968. East African seaports: an application of the concept of 'anyport'. Transactions and Papers of the Institute of British Geographers, 44, 163-183.

Jacobs, W., Notteboom, T., 2011. An evolutionary perspective on regional port systems: the role of windows of opportunity in shaping seaport competition. Environment and Planning A. 43 (7): 1674-1692.

Keeling, D. J., 2007. Transportation geography: New directions on well-worn trails. Progress in Human Geography. 31 (2): 217-225.

Knowles, R. D., 2006. Transport shaping space: differential collapse in time-space. Journal of Transport Geography. 14 (6): 407-425.

Lee, S.W., Song, D.W., Ducruet, C., 2008. A tale of Asia's world ports: the spatial evolution in global hub port cities. Geoforum 39 (1): 372-395.

Martin, C. 2013. Shipping container mobilities, seamless compatibility and the global surface of logistical integration. Environment and Planning A. 45 (5): 1021-1036.

Mohamed-Chérif, F., Ducruet, C., 2016. Regional integration and maritime connectivity across the Maghreb seaport system. Journal of Transport Geography. This issue.

Monios, J., Wilmsmeier, G., 2013. The role of intermodal transport in port regionalisation. Transport Policy. 30: 161-172.

Monios, J., Wilmsmeier, G., 2015. Identifying material, geographical and institutional mobilities in the global maritime trade system. In: Cargomobilities: moving materials in a global age. Ed: T. Birtchnell, S. Savitzky, J. Urry. Routledge: Abingdon: 125-148. 
Ng, A. K. Y., Ducruet, C., Jacobs, W., Monios, J., Notteboom, T., Rodrigue, J., Slack, B., Tam, K., Wilmsmeier, G., 2014. Port geography at the crossroads with human geography: between flows and spaces. Journal of Transport Geography. 41: 84-96.

Ng, A. K. Y., Pallis, A. A., 2010. Port governance reforms in diversified institutional frameworks: generic solutions, implementation asymmetries. Environment and Planning A. 42 (9): 2147-2167.

Niekerk, van H. C., 2005. Port reform and concessioning in developing countries. Maritime Economics and Logistics, (7): 151-155.

Notteboom, TE., 2005. The peripheral port challenge in container port systems. In International Maritime Transport: Perspectives, Edited by: Leggate, H, McConville, J and Morvillo, A. 173-188. London: Routledge.

Notteboom, T., de Langen, P., Jacobs, W., 2013. Institutional plasticity and path dependence in seaports: interactions between institutions, port governance reforms and port authority routines. Journal of Transport Geography. 27, 26-35.

Notteboom, T. E., Rodrigue, J-P., 2005. Port regionalization: towards a new phase in port development. Maritime Policy and Management. 32 (3): 297-313.

Notteboom, T., Rodrigue, J-P. 2012. The corporate geography of global container terminal operators. Maritime Policy and Management. 39 (3): 249-279.

Olivier, D., Slack, B., 2006. Rethinking the port. Environment \& Planning A. 38 (8): 14091427.

Rimmer, P. J., 1967. The search for spatial regularities in the development of Australian seaports 1861 - 1961/2. Geograkiska Annaler, 49, 42-54.

Rodrigue, J-P., Ashar, A., 2016. Transshipment Hubs in the New Panamax Era: The Role of the Caribbean. Journal of Transport Geography. This issue.

Rodrigue, J-P., Notteboom, TE., 2010. Foreland-based regionalization: Integrating intermediate hubs with port hinterlands. Research in Transportation Economics, 27: 1929.

Sánchez R. J., Wilmsmeier G., 2006. The river plate basin - A comparison of port devolution processes on the East Coast of South America. Research in Transportation Economics, 17: $185-205$.

Sánchez R. J., Wilmsmeier G., 2010. Contextual Port Development: A Theoretical Approach. In: Essays on Port Economics. Coto-Millán, P. Pesquera, M.A. and Castanedo, J.(Eds.), ISBN 9783790824247: 19-44. Springer, New York, NY, USA 
Sánchez R. J., Wilmsmeier G., 2011. Liner shipping networks and market concentration. In: International Handbook of Maritime Economics. Cullinane, K. (Ed.). Edward Elgar: Cheltenham.

Schwanen, T., Kwan, M-P., 2012. Critical space-time geographies. Environment and Planning A. 44 (9): 2043-2048.

Shaw, J., Sidaway, J. D., 2010. Making links: On (re)engaging with transport and transport geography. Progress in Human Geography. 35 (4): 502-520.

Slack, B. (1993). Pawns in the game: ports in a global transport system. Growth and Change. 24: $579-588$.

Slack, B., Wang, J. J., 2002. The challenge of peripheral ports: An Asian perspective. Geojournal, 56: 159-166.

Smith, N. 1984. Uneven development: nature, capital and the production of space. Oxford and Cambridge, MA: Blackwell.

Smith, N. 2005. Neo-critical geography, or, the flat pluralist world of business class. Antipode. 37 (5): 887-889.

Taaffe, E. J., Morrill, R. L., Gould, P. R., 1963. Transport expansion in underdeveloped countries: a comparative analysis. Geographical Review, 53, 503-529.

Thrift, N., 1996. Spatial Formations. London: Sage.

Van Klink, H. A., 1998. The port network as a new stage in port development: the case of Rotterdam. Environment and Planning A. 30 (1), 143-160.

Vonck, I., Notteboom, T., 2016. Panarchy within a port setting. Journal of Transport Geography. This issue.

Wang, C., Ducruet, C., 2012. New port development and global city making: emergence of the Shanghai-Yangshan multi-layered gateway hub. Journal of Transport Geography. 25: 58-69.

Wang, J. J., Ng, A. K. Y. 2011. The geographical connectedness of Chinese seaports with foreland markets: a new trend? Tijdschrift voor Economische en Sociale Geografie. 102 (2): 188-204.

Wilmsmeier, 2015. Geografía de transporte de carga - Evolución, desafíos en un contexto global cambiante. Serie DRNI, 175. ECLAC. Santiago de Chile

Wilmsmeier, G., Monios, J. 2013. Counterbalancing peripherality and concentration: an analysis of the UK container port system, Maritime Policy and Management, 40(2): 116132. 
Wilmsmeier, G., Monios, J., 2015. The production of capitalist "smooth" space in global port operations. Journal of Transport Geography. 47: 59-69.

Wilmsmeier, G., Monios, J., 2016. Institutional structure and agency in the governance of spatial diversification of port system evolution in Latin America. Journal of Transport Geography. This issue.

Wilmsmeier, G, Monios, J, Pérez-Salas, G., 2014. Port system evolution: the case of Latin America and the Caribbean. Journal of Transport Geography. 39: 208-221.

Wilmsmeier, G., Sánchez, R., 2011. Liner shipping networks and market concentration. In: Cullinane, K.P.B. (Ed.) Handbook of Maritime Economics (1st ed.). Cheltenham: Edward Elgar.

Zizek, S., 1999. The Ticklish Subject: The Absent Centre of Political Ontology. London: Verso. 